\title{
INTERPRETASI HASIL UJI PENETRASI KERUCUT STATIS (CONE PENETRATION TEST/CPT/SONDIR) DI KAWASAN BANDAR UDARA FATMAWATI SOEKARNO, BENGKULU
}

\author{
Hari Dwi Wahyudi' ${ }^{1}$, Dina Mutia ${ }^{2)}$ \\ 1) Teknik Sipil, Fakultas Teknik, Universitas Widya Dharma \\ Jl. Ki Hajar Dewantara, Klaten 57438. \\ Email: hariwahyudi.hdw@gmail.com \\ 2) Praktisi, PT. Penaraya Valencia \\ Jl. Tebet Raya 126 Kebonbaru, Tebet, Jakarta Selatan \\ Email: dmsir12.06@gmail.com
}

\begin{abstract}
Soil investigation is carried out to obtain data about the technical properties of the soil, which is then used for consideration in the design and implementation of construction of a structure that stands on it. In addition to obtaining conus penetration resistance $(q c)$, and shear strength resistance $(f s)$, from the sondir test results also obtained friction ratio $(f r)$, and total soil friction $(T f)$, which can be used for interpretation of soil layers. Parameters of soil characteristics include physical and mechanical properties, which are used to analyze the bearing capacity of the soil in supporting the structure above it. Sondir data can be used to obtain mechanical characteristics (such as strength, rigidity and compressibility) of Soil Be-havior Type (SBT)

Keywords: CPT, conus, shear strength, friction, total friction, interpretation of soil layers.
\end{abstract}

\begin{abstract}
Abstrak
Penyelidikan tanah dilakukan untuk mendapatkan data tentang sifat-sifat teknis tanah, yang selanjutnya digunakan untuk bahan pertimbangan dalam keperluan desain dan pelaksanaan konstruksi dari suatu struktur yang berdiri diatasnya. Selain diperoleh data nilai perlawanan penetrasi konus $(q c)$, dan hambatan lekat atau perlawanan geser $(f s)$, dari hasil uji sondir juga diperoleh data rasio gesekan ( $f r)$, dan geseran total tanah (Tf), yang dapat digunakan untuk interpretasi lapisan tanah. Parameter karakteristik tanah meliputi sifat-sifat fisik dan mekanik, yang digunakan untuk menganalisa kapasitas dukung tanah dalam menopang struktur diatasnya. Data sondir dapat digunakan untuk mendapatkan karakteristik mekanikal (seperti kekuatan, kekakuan dan kompresibilitas) dari tanah ataupun jenis tanah (Soil Behavior Type, SBT).

Kata Kunci: CPT, konus, hambatan geser, rasio gesekan, total gesekan, intepretasi lapisan tanah
\end{abstract}

\section{PENDAHULUAN}

Penyelidikan tanah (soil investigation) merupakan bagian awal dari proses yang dilakukan sebelum dimulainya pekerjaan pembangunan suatu struktur bangunan. Penyelidikan tanah dilakukan dengan 2 (dua) cara, yaitu : penyelidikan di lapangan dan pengujian di laboratorium.

Penyelidikan tanah dilakukan untuk mendapatkan data tentang sifat-sifat teknis tanah, yang selanjutnya digunakan untuk bahan pertimbangan dalam keperluan desain dan pelaksanaan konstruksi dari suatu struktur yang berdiri diatasnya. Secara rinci, tujuan penyelidikan tanah adalah :

1. untuk memperoleh informasi awal kondisi tanah dasar, dan mengidentifikasi kemungkinan desain alternatif, serta memungkinkan penyelidikan yang lebih lengkap untuk direncanakan,

2. untuk memperoleh informasi lengkap dari kondisi tanah dalam merencanakan metode perbaikan tanah yang tepat untuk timbunan dan fondasi jembatan serta konstruksi lainnya,

3. untuk menyediakan informasi mengenai kondisi tanah dasar,

4. untuk memperoleh informasi tambahan pada lokasi tertentu untuk mengklarifikasi kondisi tanah, sehingga desain strukturnya menjadi lengkap.
Salah satu metode penyelidikan tanah yang dilakukan di lapangan, adalah : uji penetrasi kerucut statis (Conus Penetration Test/CPT/Sondir). CPT merupakan metode yang digunakan untuk menentukan sifat rekayasa geoteknik tanah dan menggambarkan stratigrafi tanah. Saat ini, CPT adalah salah satu metode tanah yang paling banyak digunakan dan diterima untuk penyelidikan tanah di seluruh dunia. Dari metode penyelidikan tanah ini didapatkan nilai perlawanan penetrasi konus $(q c)$ dan hambatan lekat atau perlawanan geser $(f s)$.

\section{KAJIAN PUSTAKA}

\section{Uji Penetrasi Kerucut Statis (Conus Penetration} Test/CPT/Sondir)

Selain diperoleh data nilai perlawanan penetrasi konus $(q c)$, dan hambatan lekat atau perlawanan geser $(f s)$, dari hasil uji sondir juga diperoleh data rasio gesekan $(f r)$, dan geseran total tanah $(T f)$, yang dapat digunakan untuk intepretasi lapisan tanah.

a. Nilai Perlawanan Penetrasi Konus $(q c)$

Perlawanan penetrasi konus $(q c)$ adalah nilai perlawanan terhadap gerakan penetrasi konus yang besarnya sama dengan gaya vertikal yang bekerja pada konus dibagi dengan luas ujung konus.

b. Hambatan Lekat Atau Perlawanan Geser $(f s)$

Hambatan lekat atau perlawanan geser $(f s)$ merupakan nilai perlawanan terhadap gerakan penetrasi akibat 
geseran yang besarnya sama dengan gaya vertikal, yang bekerja pada bidang geser dibagi dengan luas permukaan selimut geser; perlawanan ini terdiri atas jumlah geseran dan gaya adhesi.

c. Rasio Gesekan $(R f)$

Merupakan nilai yang diperoleh dari perbandingan antara nilai perlawanan geser dengan nilai perlawanan penetrasi konus $\left(f_{s} / q c\right)$, yang dinyatakan dalam persen.

d. Geseran Total Tanah (Tf)

Nilai geseran total merupakan nilai tahanan atau tegangan geser maksimum yang dapat ditahan oleh tanah pada kondisi pembebanan tertentu.

\section{Parameter Karakteristik Tanah}

Parameter karakteristik tanah meliputi sifat-sifat fisik dan mekanik, yang digunakan untuk menganalisa kapasitas dukung tanah dalam menopang struktur diatasnya. Secara tipikal, tahanan konus tinggi pada pasir dan rendah pada lempung, dan rasio gesekan ( $f r$ ) rendah pada pasir dan tinggi pada lempung. Data sondir dapat digunakan untuk mendapatkan karakteristik mekanikal (seperti kekuatan, kekakuan dan kompresibilitas) dari tanah ataupun jenis tanah (Soil Behavior Type, SBT). Salah satu metode intepretasi data CPT terhadap karakteristik tanah diusulkan oleh Robertson (1990, diperbarui 2010), sebagai berikut :

a. Klasifikasi Tanah

Klasifikasi tanah bertujuan untuk mengelompokkan tanah menurut berbagai kualitas dan karakteristik. Secara umum sistem klasifikasi tanah yang digunakan dalam rekayasa geoteknik didasarkan pada karakteristik fisik, seperti : ukuran butiran, dan batas batas plastisitas tanah tersebut. Klasifikasi tanah dengan data CPT yang diusulkan oleh Robertson (1990), berdasarkan pada karakteristik perilaku tanah sehingga sering disebut sebagai sistem klasifikasi jenis perilaku tanah (Soil Behavior Type).Perkiraan tentang tipe tanah yang didasarkan pada CPT merujuk kepada Soil Behavior Type (SBT) seperti pada Gambar 1.

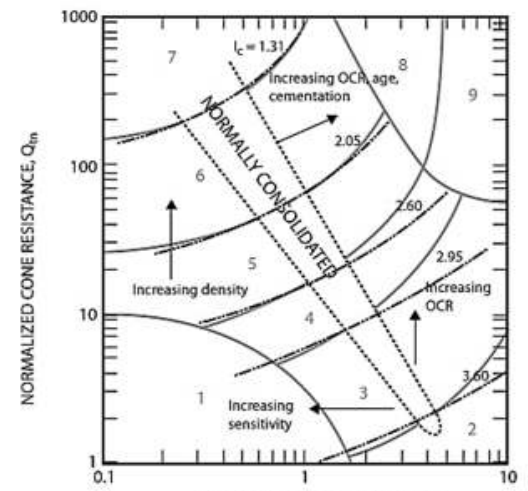

NORMALIZED FRICTION RATIO, F,

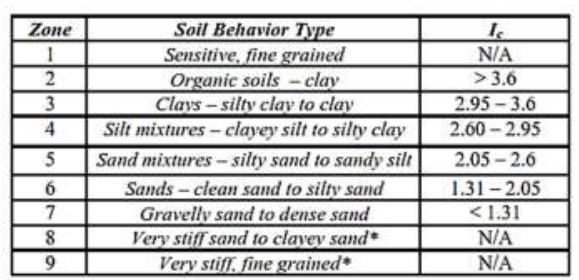

Gambar 1. Grafik profil tipe tanah berdasarkan data CPT (Robertson, 2010).
Untuk menyederhanakan dalam analisa dibuat pembagian zona tipe tanah yang diklasifikasikan dalam suatu index (Ic) sebagai fungsi dari tahanan konus dan rasio gesekan. Nilai Ic dapat dihitung dengan persamaan berikut :

$$
I_{c}=\left[\left(3,47-\log Q_{t}\right)^{2}+\left(\log R_{f}+1,22\right)^{2}\right]^{0,5}
$$

dimana ;

Qt $=$ tahanan konus ternormalisasi

$R f=$ rasio gesek

b. Berat Volume Tanah

Material tanah dapat terdiri atas dua atau tiga unsur, yakni butiran, air dan udara. Pada dalam kondisi tanah jenuh terdapat dua unsur, yakni butiran dan air, dan pada tanah yang kering juga hanya terdapat dua unsur yakni butiran dan udara. Sedangkan pada tanah dengan kondisi tak jenuh terdapat tiga unsur, yakni butiran, air dan udara. Masing-masing elemen tanah tersebut (butir, air dan udara), memiliki volume dan berat. Berat volume tanah merupakan perbandingan antara berat butiran tanah (termasuk air dan udara) dibagi dengan volume total tanah. Dalam analisa dapat CPT, nilai berat volume tanah dihitung dengan persamaan sebagai berikut :

$$
\gamma / \gamma_{w}=0,27 \log R_{f}+0,36 \log \left(\frac{q_{t}}{p_{a}}\right)+1,236
$$

dimana :

$R f=$ rasio gesekan $=(f s / q t) 100 \%$

$\gamma \mathrm{W}=$ berat volume air

$q t=$ nilai konus terkoreksi

pa $=$ tekanan $1 \mathrm{~atm}$

Soil Unit Weights, $\gamma / \gamma_{\mathrm{w}}$ $\left(\gamma_{w}=\right.$ unit weight of water)

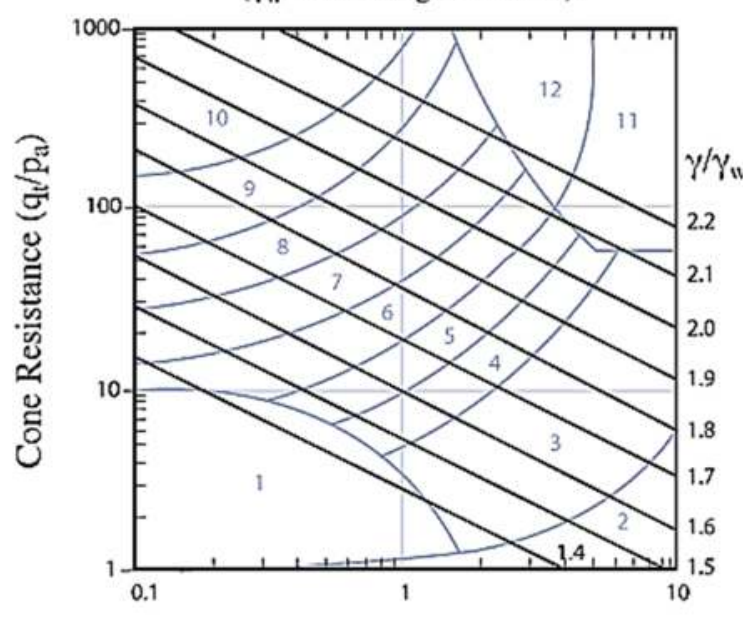

Friction Ratio, $\mathrm{R}_{\mathrm{f}}=\left(\mathrm{f}_{\mathrm{s}} / \mathrm{q}_{\mathrm{t}}\right) \times 100(\%)$

Gambar 2. Grafik berat volume tanah berdasarkan data CPT (Robertson, 2010).

c. Kohesi

Kohesi adalah kemampuan tarik menarik antar partikel tanah. Dengan menggunakan asumsi pada kondisi undrained maka untuk tanah lempung $\mathrm{s}_{\mathrm{u}}=\mathrm{c}_{\mathrm{u}}$. 
Hubungan antara tahanan konus dengan su diperlihatkan dalam persamaan berikut ;

$$
C_{u}=\frac{q_{c}}{N_{c}}
$$

dimana :

$\mathrm{Nc}=14$

$q c=$ nilai konus

d. Sudut Geser

Sudut geser dalam merupakan sudut yang dibentuk dari hubungan antara tegangan normal dan tegangan geser di dalam material tanah. Sudut geser dalam adalah sudut rekahan yang dibentuk jika suatu material dikenai tegangan atau gaya terhadapnya yang melebihi tegangan gesernya. Semakin besar sudut geser dalam material maka material tersebut akan lebih tahan menerima tegangan luar yang dikenakan terhadapnya. Robertson dan Campanella (1983) menyarankan korelasi untuk memperkirakan puncak sudut geser dengan persamaan:

$$
\tan \varphi^{\prime}=\frac{1}{2,68}\left[\log \left(\frac{q_{c}}{\sigma_{v o}^{\prime}}\right)+0,29\right]
$$

dimana :

$\mathrm{qc}=$ nilai konus

$\sigma^{\prime} v o=$ tegangan vertikal efektif

e. Permeabilitas

Nilai pendekatan parameter permeabilitas dapat dilakukan dengan menggunakan hasil evaluasi grafik CPT.

\begin{tabular}{|c|c|c|c|}
\hline $\begin{array}{l}\text { SBT } \\
\text { Zone }\end{array}$ & SBT & $\begin{array}{l}\text { Range of } k \\
(\mathrm{~m} / \mathrm{s})\end{array}$ & SBT $I_{e}$ \\
\hline 1 & Sensitive fine-grained & $3 \times 10^{-10}$ to $3 \times 10^{-8}$ & $N A$ \\
\hline 2 & Organic soils - clay & $1 \times 10^{-10}$ to $1 \times 10^{-8}$ & $I_{c}>3.60$ \\
\hline 3 & Clay & $1 \times 10^{-10}$ to $1 \times 10^{-9}$ & $2.95<I_{c}<3.60$ \\
\hline 4 & Silt mixture & $3 \times 10^{-9}$ to $1 \times 10^{-7}$ & $2.60<I_{c}<2.95$ \\
\hline 5 & Sand mixture & $1 \times 10^{-7}$ to $1 \times 10^{-5}$ & $2.05<I_{c}<2.60$ \\
\hline 6 & Sand & $1 \times 10^{-3}$ to $1 \times 10^{-3}$ & $1.31<I_{c}<2.05$ \\
\hline 7 & Dense sand to gravelly sand & $1 \times 10^{-3}$ to 1 & $I_{c}<1.31$ \\
\hline 8 & *Very dense/ stiff soil & $1 \times 10^{-8}$ to $1 \times 10^{-3}$ & $N A$ \\
\hline 9 & *Very stiff fine-grained soil & $1 \times 10^{-9}$ to $1 \times 10^{-7}$ & $N A$ \\
\hline
\end{tabular}

Tabel 1. Nilai Perkiraan Permeabilitas

Hubungan antara permeabilitas tanah (k) dengan SBT Ic dalam Tabel 1 direpresentasikan dengan persamaan berikut :

\begin{tabular}{cc}
\hline $\begin{array}{c}\text { Permeabilitas tanah, } k \\
(\mathrm{~m} / \text { detik })\end{array}$ & Keterangan \\
\hline$k=10^{\left(0,952-3,04 I_{c}\right)}$ & $1<I_{c}<3,27$ \\
$k=10^{\left(-4,52-1,37 I_{c}\right)}$ & $3,27<I_{c}<4,00$ \\
\hline
\end{tabular}

\section{METODE PENELITIAN}

Data yang digunakan dalam analisis ini adalah data hasil penyelidikan tanah Pembangunan Gedung Terminal Bandar Udara Fatmawati Bengkulu. Alat yang digunakan adalah Dutch Cone Penetration Test (CPT) kapasitas 2,5 ton dengan kecepatan penetrasi selama pengujian tidak lebih dari $2 \mathrm{~cm} /$ detik. Selanjutnya, analisa intepretasi data dilakukan dengan menggunakan program bantu Microsoft Excel.

\section{HASIL ANALISA \\ Data Hasil Penyelidikan Tanah}

Penyelidikan tanah dengan metode CPT yang dilakukan pada 3 titik lokasi yang berbeda di kawasan Bandar Udara Fatmawati Soekarno - Bengkulu, adalah sebagai berikut :

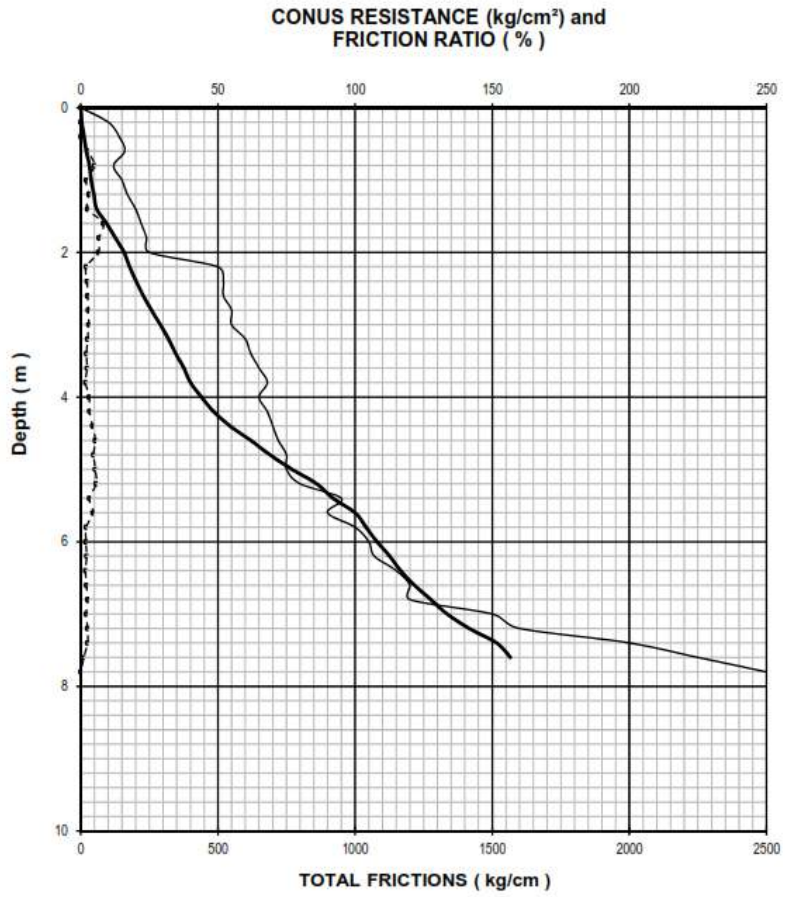

Gambar 3. Grafik penyelidikan tanah CPT titik 1. (Sumber : Laporan penyelidikan geoteknik, PT. Penaraya)

Tabel 2. Hasil Penyelidikan Tanah Dengan CPT Titik 1

\begin{tabular}{cccccccc}
\hline \multirow{2}{*}{$\begin{array}{c}\text { Kode } \\
\text { Titik CPT }\end{array}$} & \multicolumn{6}{c}{ Kedalaman } & \multicolumn{6}{c}{$\begin{array}{c}\mathrm{q}_{c} \\
\mathrm{~kg} / \mathrm{cm}^{2}\end{array}$} & $\begin{array}{c}f s \\
\mathrm{~kg} / \mathrm{cm}^{2}\end{array}$ & $\begin{array}{c}\mathrm{T}_{f} \\
\mathrm{~kg} / \mathrm{cm}^{2}\end{array}$ & $\begin{array}{c}R f \\
\%\end{array}$ \\
\cline { 2 - 8 } & & & 11,00 & 3,00 & 18,00 & 2,00 \\
& 0,00 & s.d & 1,00 & & & \\
& 1,00 & s.d & 2,00 & 21,00 & 11,00 & 87,00 & 5,00 \\
& 2,00 & s.d & 3,00 & 48,00 & 14,00 & 219,00 & 3,00 \\
CPT-1 & 3,00 & s.d & 4,00 & 63,00 & 15,00 & 362,00 & 2,00 \\
& 4,00 & s.d & 5,00 & 71,00 & 31,00 & 591,00 & 4,00 \\
& 5,00 & s.d & 6,00 & 91,00 & 33,00 & 945,00 & 4,00 \\
& 6,00 & s.d & 7,00 & 120,00 & 38,00 & 1200,00 & 2,00 \\
& 7,00 & s.d & 8,00 & 250,00 & 40,00 & 1167,00 & 2,00 \\
\hline
\end{tabular}

Pada titik CPT- 1, nilai rerata tahanan konus (qc) pada kedalaman 0,00 s.d 1,00 m dari permukaan tanah sebesar $11,00 \mathrm{~kg} / \mathrm{cm}^{2}$ yang selanjutnya bertambah hingga nilai $250 \mathrm{~kg} / \mathrm{cm}^{2}$ pada kedalaman $8,00 \mathrm{~m}$ dari permukaan tanah. Nilai perlawanan geser $(f s)$ pada titik CPT-1, mempunyai nilai rerata yang berkisar dari 3,00 s.d 29,00 $\mathrm{kg} / \mathrm{cm}^{2}$. Nilai geseran total (Tf) yang merupakan kemampuan tanah untuk menahan beban semakin bertambah hingga mencapai nilai rerata $1167,00 \mathrm{~kg} / \mathrm{cm} 2$ pada kedalaman antara 7,00 s.d 8,00 m dari permukaan tanah. Nilai rasio gesek $(R f)$ pada titik CPT-1, mempunyai nilai $>1 \%$. 


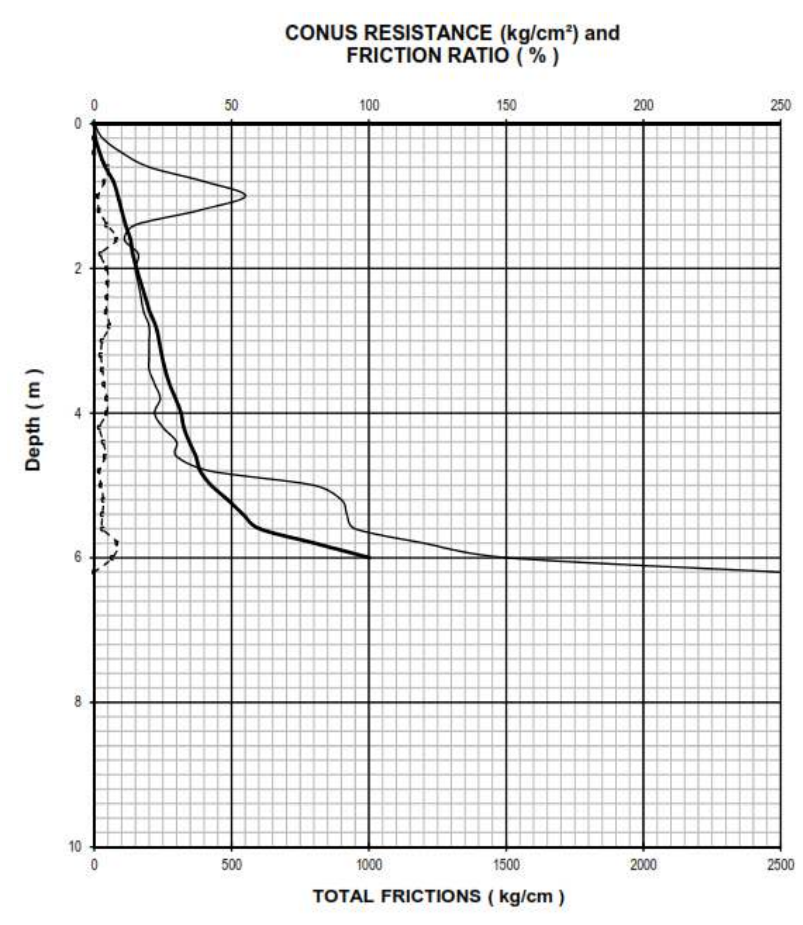

Gambar 4. Grafik penyelidikan tanah CPT titik 2. (Sumber : Laporan penyelidikan geoteknik, PT. Penaraya)

Tabel 3. Hasil Penyelidikan Tanah Dengan CPT Titik 2

\begin{tabular}{|c|c|c|c|c|c|c|c|}
\hline \multirow{3}{*}{$\begin{array}{c}\text { Kode } \\
\text { Titik CPT }\end{array}$} & \multicolumn{7}{|c|}{ Data Hasil CPT } \\
\hline & \multirow{2}{*}{\multicolumn{3}{|c|}{$\begin{array}{c}\text { Kedalaman } \\
\mathrm{m}\end{array}$}} & \multirow{3}{*}{$\begin{array}{c}\begin{array}{c}\mathrm{q}_{\mathrm{c}} \\
\mathrm{kg} / \mathrm{cm}^{2}\end{array} \\
21,00\end{array}$} & \multirow{3}{*}{$\begin{array}{c}\begin{array}{c}f \mathrm{~s} \\
\mathrm{~kg} / \mathrm{cm}^{2}\end{array} \\
7,00\end{array}$} & \multirow{3}{*}{$\begin{array}{c}\begin{array}{c}\mathrm{T}_{\mathrm{f}} \\
\mathrm{kg} / \mathrm{cm}^{2}\end{array} \\
37,00\end{array}$} & \multirow{3}{*}{$\begin{array}{c}R f \\
\% \\
2,00\end{array}$} \\
\hline & & & & & & & \\
\hline \multirow{7}{*}{ CPT-2 } & 0,00 & s.d & 1,00 & & & & \\
\hline & 1,00 & s.d & 2,00 & 25,00 & 7,00 & 121,00 & 4,00 \\
\hline & 2,00 & s.d & 3,00 & 18,00 & 8,00 & 195,00 & 5,00 \\
\hline & 3,00 & s.d & 4,00 & 21,00 & 8,00 & 271,00 & 4,00 \\
\hline & 4,00 & s.d & 5,00 & 38,00 & 11,00 & 362,00 & 3,00 \\
\hline & 5,00 & s.d & 6,00 & 105,00 & 51,00 & 643,00 & 5,00 \\
\hline & 6,00 & s.d & 6,20 & 250,00 & 75,50 & 501,00 & 3,00 \\
\hline
\end{tabular}

Pada titik CPT- 2, nilai rerata tahanan konus (qc) pada kedalaman 0,00 s.d 1,00 m dari permukaan tanah sebesar $21,00 \mathrm{~kg} / \mathrm{cm}^{2}$ yang selanjutnya bertambah hingga nilai $250 \mathrm{~kg} / \mathrm{cm}^{2}$ pada kedalaman $6,20 \mathrm{~m}$ dari permukaan tanah. Nilai perlawanan geser $(f s)$ pada titik CPT-2, mempunyai nilai rerata yang berkisar dari 7,00 s.d 100,00 $\mathrm{kg} / \mathrm{cm}^{2}$. Nilai geseran total (Tf) yang merupakan kemampuan tanah untuk menahan beban semakin bertambah hingga mencapai nilai rerata $501,00 \mathrm{~kg} / \mathrm{cm} 2$ pada kedalaman antara 6,00 s.d $6,20 \mathrm{~m}$ dari permukaan tanah. Nilai rasio gesek $(R f)$ pada titik CPT-2, mempunyai nilai $>1 \%$.

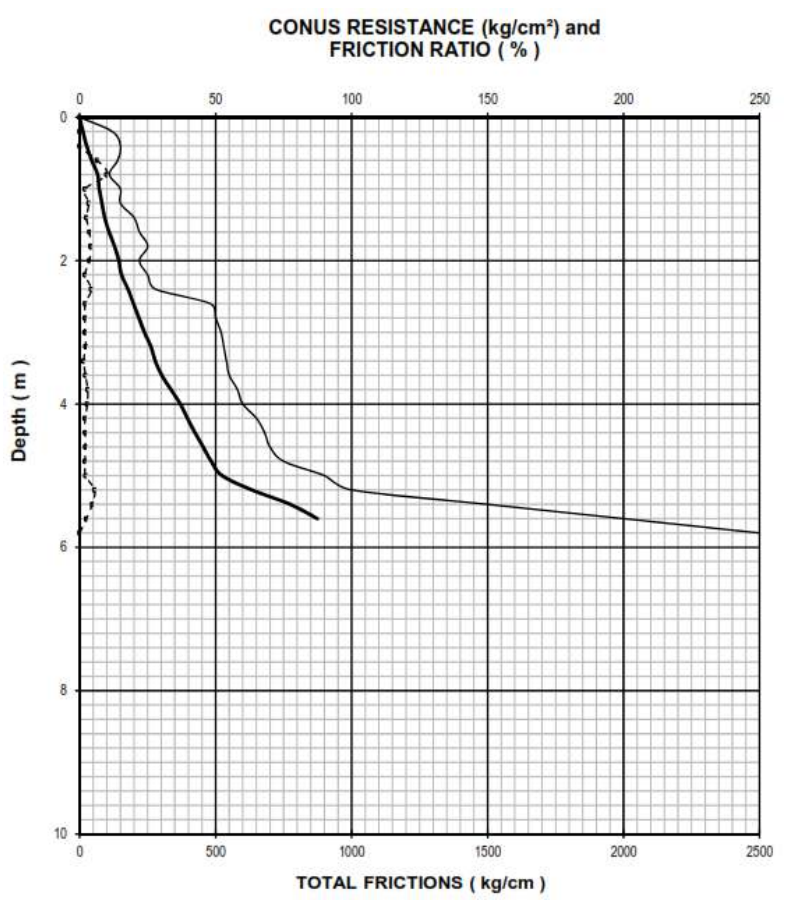

Gambar 5. Grafik penyelidikan tanah CPT titik 3. (Sumber : Laporan penyelidikan geoteknik, PT. Penaraya)

Tabel 4. Hasil Penyelidikan Tanah Dengan CPT Titik 3

\begin{tabular}{|c|c|c|c|c|c|c|c|}
\hline \multirow[b]{2}{*}{$\begin{array}{c}\text { Kode } \\
\text { Titik CPT }\end{array}$} & \multicolumn{7}{|c|}{ Data Hasil CPT } \\
\hline & \multicolumn{3}{|c|}{$\begin{array}{c}\text { Kedalaman } \\
\mathrm{m}\end{array}$} & \multirow{2}{*}{$\begin{array}{c}\begin{array}{c}\mathrm{q}_{\mathrm{c}} \\
\mathrm{kg} / \mathrm{cm}^{2}\end{array} \\
11,00\end{array}$} & \multirow{2}{*}{$\begin{array}{c}\begin{array}{c}f \mathrm{~s} \\
\mathrm{~kg} / \mathrm{cm}^{2}\end{array} \\
6,00\end{array}$} & \multirow{2}{*}{$\begin{array}{c}\begin{array}{c}\mathrm{T}_{\mathrm{f}} \\
\mathrm{kg} / \mathrm{cm}^{2}\end{array} \\
37,00\end{array}$} & \multirow{2}{*}{$\begin{array}{c}R f \\
\% \\
3,00\end{array}$} \\
\hline \multirow{6}{*}{ CPT -3} & 0,00 & s.d & 1,00 & & & & \\
\hline & 1,00 & s.d & 2,00 & 20,00 & 7,00 & 104,00 & 3,00 \\
\hline & 2,00 & s.d & 3,00 & 38,00 & 9,00 & 188,00 & 3,00 \\
\hline & 3,00 & s.d & 4,00 & 55,00 & 13,00 & 298,00 & 2,00 \\
\hline & 4,00 & s.d & 5,00 & 71,00 & 16,00 & 442,00 & 2,00 \\
\hline & 5,00 & s.d & 5,80 & 250,00 & 70,00 & 561,00 & 3,00 \\
\hline
\end{tabular}

Pada titik CPT- 3, nilai rerata tahanan konus (qc) pada kedalaman 0,00 s.d 1,00 m dari permukaan tanah sebesar $11,00 \mathrm{~kg} / \mathrm{cm}^{2}$ yang selanjutnya bertambah hingga nilai $250 \mathrm{~kg} / \mathrm{cm}^{2}$ pada kedalaman $5,80 \mathrm{~m}$ dari permukaan tanah. Nilai perlawanan geser $(f s)$ pada titik CPT-3, mempunyai nilai rerata yang berkisar dari 6,00 s.d 70,00 $\mathrm{kg} / \mathrm{cm}^{2}$. Nilai geseran total (Tf) yang merupakan kemampuan tanah untuk menahan beban semakin bertambah hingga mencapai nilai rerata $561,00 \mathrm{~kg} / \mathrm{cm} 2$ pada kedalaman antara 5,00 s.d 5,80 m dari permukaan tanah. Nilai rasio gesek $(R f)$ pada titik CPT-3, mempunyai nilai $>1 \%$.

\section{Analisa Hasil Penyelidikan Tanah Metode CPT}

Nilai tahanan konus $\left(q_{c}\right)$ yang merupakan perlawanan ujung sondir yang bersentuhan langsung dengan tanah, terhadap besarnya gaya yang memberikan penetrasi. Nilai tahanan ujung diukur sebagai gaya penetrasi persatuan luas penampang ujung konus $\left(q_{c}\right)$. Besarnya nilai ini menunjukkan identifikasi jenis tanah, semakin besar nilai tahanan konus $\left(q_{c}\right)$ maka tanah mempunyai butiran partikel yang semakin padat. 
Nilai perlawanan geser $\left(f_{s}\right)$ diperoleh dari hasil pengukuran perlawanan ujung konus dan selimut bersamasama ditekan ke dalam tanah dikurang hasil pengukuran tahanan ujung konus dengan kedalaman penetrasi yang sama. Nilai perlawanan geser $\left(f_{s}\right)$ diukur sebagai gaya penetrasi persatuan luas selimut konus. Nilai perlawanan geser $\left(f_{s}\right)$ digunakan untuk menginterpretasikan sifat-sifat tanah untuk klasifikasi tanah, dimana pada tanah kohesif mempunyai nilai perlawanan geser yang tinggi.

Nilai rasio gesek $(R f)$ merupakan perbandingan antara gesekan selimut $(f s)$ dengan tahanan ujung $(q c)$. Rasio gesek $(R f)$ dari hasil CPT dapat digunakan untuk membedakan tanah berbutir halus dengan tanah yang berbutir kasar (memperkirakan jenis tanah yang diselidiki). $R f<1 \%$; tanah granuler, $R f>1 \%$; tanah kohesif.

\section{Parameter Tanah Berdasarkan Interpretasi Data CPT}

Selanjutnya data hasil penyelidikan tersebut diolah untuk menentukan parameter tanah, yang meliputi : berat volume, kohesi, sudut geser, permeabilitas, dan klasifikasi tanah. Tabel di bawah ini merupakan hasil pengolahan data penyelidikan tanah.

Tabel 5. Hasil Analisa Data Hasil CPT

\begin{tabular}{|c|c|c|c|c|c|c|c|c|}
\hline \multirow[b]{2}{*}{$\begin{array}{c}\text { Kode } \\
\text { Titik CPT }\end{array}$} & \multicolumn{3}{|c|}{ Kedalaman } & \multicolumn{5}{|c|}{ Hasil Intepretasi Parameter Tanah } \\
\hline & \multicolumn{3}{|c|}{$\mathrm{m}$} & $\begin{array}{c}\gamma \\
\mathrm{t} / \mathrm{m}^{3}\end{array}$ & $\begin{array}{c}\mathrm{c}_{\mathrm{u}} \\
\mathrm{kg} / \mathrm{cm}^{2}\end{array}$ & $\varphi$ & $\begin{array}{c}\mathrm{k} \\
\mathrm{m} / \mathrm{dtk}\end{array}$ & $\overline{i_{c}}$ \\
\hline \multirow{8}{*}{$\mathrm{CPT}-1$} & 0,00 & s.d & 1,00 & 1,85 & 0,80 & 2,83 & $2,20 \mathrm{E}-09$ & 3,21 \\
\hline & 1,00 & s.d & 2,00 & 1,87 & 1,46 & 2,69 & $2,91 \mathrm{E}-09$ & 3,16 \\
\hline & 2,00 & s.d & 3,00 & 1,90 & 3,44 & 2,69 & $5,05 \mathrm{E}-09$ & 3,09 \\
\hline & 3,00 & s.d & 4,00 & 1,93 & 4,46 & 2,77 & 7,71E-09 & 3,02 \\
\hline & 4,00 & s.d & 5,00 & 1,95 & 5,06 & 2,77 & $1,05 \mathrm{E}-08$ & 2,97 \\
\hline & 5,00 & s.d & 6,00 & 1,96 & 6,49 & 3,32 & $1,36 \mathrm{E}-08$ & 2,92 \\
\hline & 6,00 & s.d & 7,00 & 1,96 & 8,54 & 3,71 & $1,67 \mathrm{E}-08$ & 2,89 \\
\hline & 7,00 & s.d & 8,00 & 1,97 & 14,07 & 4,13 & $2,02 \mathrm{E}-08$ & 2,85 \\
\hline \multirow{7}{*}{ CPT-2 } & 0,00 & s.d & 1,00 & 1,87 & 2,04 & 3,37 & $5,68 \mathrm{E}-09$ & 3,11 \\
\hline & 1,00 & s.d & 2,00 & 1,85 & 2,29 & 3,27 & $3,80 \mathrm{E}-09$ & 3,17 \\
\hline & 2,00 & s.d & 3,00 & 1,84 & 1,83 & 2,85 & $2,03 \mathrm{E}-09$ & 3,21 \\
\hline & 3,00 & s.d & 4,00 & 1,84 & 2,07 & 2,52 & $1,32 \mathrm{E}-09$ & 3,24 \\
\hline & 4,00 & s.d & 5,00 & 1,84 & 3,50 & 2,54 & $1,43 \mathrm{E}-09$ & 3,23 \\
\hline & 5,00 & s.d & 6,00 & 1,85 & 11,13 & 2,79 & $1,76 \mathrm{E}-09$ & 3,20 \\
\hline & 6,00 & s.d & 6,20 & 1,86 & 17,86 & 2,73 & $1,93 \mathrm{E}-09$ & 3,18 \\
\hline \multirow{6}{*}{$\mathrm{CPT}-3$} & 0,00 & s.d & 1,00 & 1,83 & 1,23 & 3,05 & $1,88 \mathrm{E}-09$ & 3,22 \\
\hline & 1,00 & s.d & 2,00 & 1,83 & 1,88 & 3,64 & $2,20 \mathrm{E}-09$ & 3,19 \\
\hline & 2,00 & s.d & 3,00 & 1,85 & 3,33 & 3,64 & $2,44 \mathrm{E}-09$ & 3,16 \\
\hline & 3,00 & s.d & 4,00 & 1,87 & 4,86 & 3,54 & $3,23 \mathrm{E}-09$ & 3,12 \\
\hline & 4,00 & s.d & 5,00 & 1,89 & 6,21 & 3,59 & $5,09 \mathrm{E}-09$ & 3,07 \\
\hline & 5,00 & s.d & 5,80 & 1,90 & 14,07 & 3,78 & $6,89 \mathrm{E}-09$ & 3,03 \\
\hline
\end{tabular}

Sumber : Hasil analisa

Nilai index Ic sebagai parameter untuk menentukan klasifikasi tanah berdasarkan perilaku (SBT) dipengaruhi oleh nilai tahanan konus ternormalisasi $(Q t)$ dan nilai rasio gesek $(R f)$. Nilai index $I c$ yang semakin tinggi, memberikan deskripsi bahwa tanah tersebut mempunyai butiran yang halus. Hasil analisa dan perhitungan nilai index Ic yang disajikan pada tabel 5, sampai dengan kedalaman 6,00 dari permukaan tanah menunjukkan nilai yang relatif seragam. Nilai index Ic berkisar antara 2,85 sampai dengan 3,24 yang selanjutnya ditunjukkan pada grafik SBT pada Gambar 6.

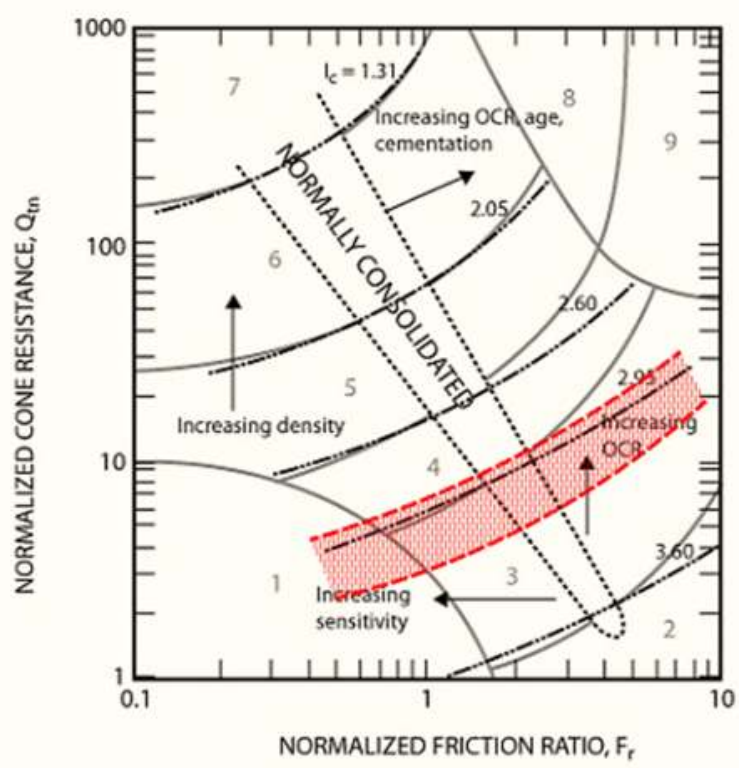

Gambar 6. Grafik profil jenis tanah berdasarkan index Ic (Sumber : Hasil analisa)

Pada grafik profil jenis tanah pada Gambar 6 menunjukkan bahwa tanah tersebut termasuk dalam klasifikasi tanah kohesif, dimana kohesifitasnya mempunyai nilai maximum $17,86 \mathrm{~kg} / \mathrm{cm}^{2}$. Grafik hubungan antara rasio gesek $(R f)$ dengan tahanan konus $(q c)$ dan berat volume tanah $(\gamma)$ ditunjukkan pada Gambar 7. Nilai berat volume tanah $(\gamma)$ berkisar antara $1,83 \mathrm{t} / \mathrm{m}^{3}$ sampai dengan $1,97 \mathrm{t} / \mathrm{m}^{3}$. Sedangkan nilai sudut gesek tanah $(\varphi)$ relatif kecil dan seragam dengan nilai kurang dari $5^{\circ}$. Permeabilitas tanah yang merupakan kemampuan tanah untuk mengalirkan air melalui pori - porinya, mempunyai nilai terbesar $2,02 \times 10^{-8} \mathrm{~m} /$ detik. Nilai permeabilitas yang kecil menunjukkan bahwa tanah mempunyai butiran yang halus dan kepadatan tinggi.

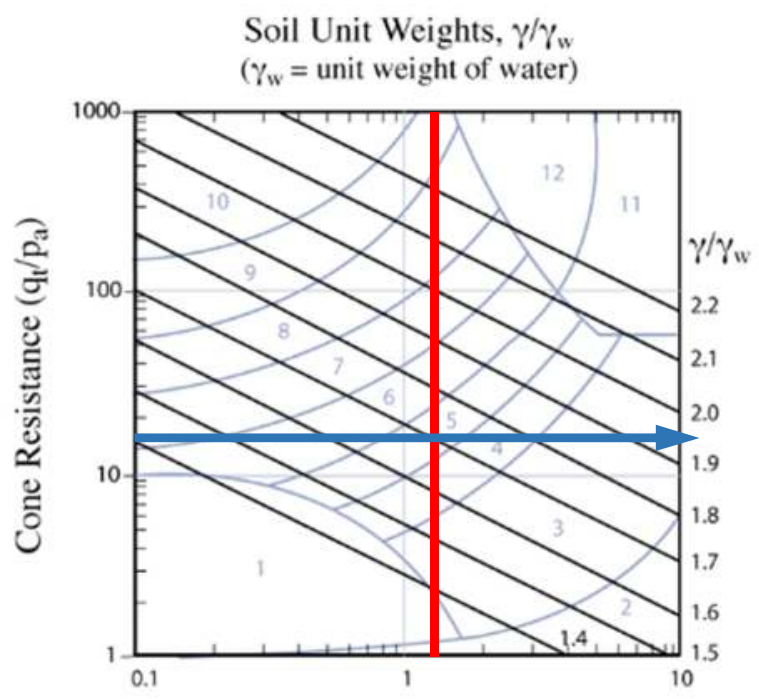

Friction Ratio, $\mathrm{R}_{\mathrm{f}}=\left(\mathrm{f}_{\mathrm{s}} / \mathrm{q}_{\mathrm{t}}\right) \times 100(\%)$

Gambar 7. Grafik profil jenis tanah berdasarkan index Ic (Sumber : Hasil analisa) 


\section{KESIMPULAN}

Dari hasil interpretasi hasil penyelidikan tanah metode CPT dengan jenis tanah dan beberapa parameter tanah yang telah dibahas, maka ditarik beberapa kesimpulan sebagai berikut :

1. Hasil penyelidikan tanah dengan CPT pada kedalaman sampai dengan $1,00 \mathrm{~m}$ dari atas permukaan tanah memberikan nilai tahanan konus $\left(\mathrm{q}_{\mathrm{c}}\right)$ berkisar antara $11,00 \mathrm{~kg} / \mathrm{cm}^{2}$ dan semakin bertambah hingga mencapai nilai $250,00 \mathrm{~kg} / \mathrm{cm}^{2}$ pada kedalaman di bawah $6,00 \mathrm{~m}$ dari permukaan tanah. Nilai perlawanan geser $(f s)$ mengalami peningkatan yang relatif signifikan pada kedalaman dibawah 5,00 $\mathrm{m}$ dari permukaan tanah. Nilai rasio gesek $(R f)$ cenderung untuk berubah pada tiap - tiap kedalaman, namun nilai rasio gesek yang terjadi relatif stabil pada kisaran $>1$ $\%$.

2. Berdasarkan hasil penyelidikan tanah dengan metode CPT didapatkan nilai tahanan konus $\left(\mathrm{q}_{\mathrm{c}}\right)$, nilai perlawanan geser $(f s)$, dan nilai rasio gesek $(R f)$ yang relatif sama, hasil tersebut digunakan untuk menentukan jenis tanah dan beberapa parameter tanah, yaitu ; berat volume, kohesi, sudut gesek, dan permeabilitas.

3. Nilai index Ic, secara umum hasilnya mempunyai nilai yang sama terhadap titik CPT yang berbeda namun masih dalam kawasan penyelidikan yang sama. Hal ini menunjukkan bahwa jenis tanah yang diselidiki cenderung seragam.

4. Berdasarkan nilai index Ic, tanah yang diselidiki mempunyai butiran yang relatif halus dan termasuk dalam klasifikasi tanah lempung.

5. Hasil analisa menunjukkan bahwa tanah yang dilakukan penyelidikan termasuk dalam klasifikasi jenis tanah lempung dengan nilai sudut gesek dan permeabilitas yang relatif kecil.

6. Disarankan untuk membandingkan kajian interpretasi hasil penyelidikan tanah metode CPT ini dengan hasil pengujian contoh tanah di Laboratorium dan dibandingkan pula dengan kajian hasil penyelidikan tanah metode SPT.

\section{Ucapan Terima Kasih}

Ucapan terimakasih disampaikan kepada Ibu Ne'imah Baidani, S.T. dari PT. Penaraya Valencia, sebagai ketua pelaksana tim penyusun rencana teknis terinci Bandar Udara Fatmawati Soekarno, Bengkulu.

\section{DAFTAR PUSTAKA}

Apriyono, A., (2017), "Soil Classification Based on Cone Penetration Test (CPT) Data in Western Central Java", Engineering International Conference (EIC 2017), AIP Publishing, 2018. Diunduh, 18 Agustus 2018.

Hardiyatmo, H.C, (2006), Mekanika Tanah 1, Gadjah Mada Universty Press, Yogyakarta.

Robertson, P.K., (2012), Guide to Cone Penetration Testing, Gregg Drilling \& Testing, Inc., California.

Robertson, P.K., "Cone Penetration Test - best soil behavior type (SBT) classification system - an update". www.nrcresearchpress.com, published 14 July 2018. Diunduh, 18 Agustus 2018.

Tim Geoteknik, (2017), Laporan Soil Invetigation Bandar Udara Fatmawati Soekarno, PT. Penaraya Valencia, Jakarta.

Wesley, L.D., (2011), Mekanika Tanah, Penerbit ANDI, Jakarta. 